\title{
SURVEILLANCE OF Ganoderma DISEASE IN OIL PALM PLANTED BY PARTICIPANTS OF THE SMALLHOLDERS REPLANTING INCENTIVE SCHEME IN MALAYSIA
}

\section{MOHD SHUKRI IBRAHIM*; IDRIS ABU SEMAN*; MOHD HEFNI RUSLI*; MOHAMAD ANUAR IZZUDDIN*; NORMAN KAMARUDIN*; KHAIRUMAN HASHIM* and ZULKIFLI ABD MANAF*}

\begin{abstract}
A ground surveillance of basal stem rot disease (BSR) caused by pathogenic fungus Ganoderma sp. in oil palm was conducted by the Malaysian Palm Oil Board (MPOB) to determine status of incidence and distribution of Ganoderma disease of the smallholders (SH) particularly participating in the replanting incentive scheme in Malaysia. This survey was conducted for detection either presence or absence of BSR disease in oil palms areas with a total area of 37359.81 ha involving 10292 smallholders including in Peninsular, Sabah and Sarawak. The survey consisted of visual identification of BSR disease symptoms on mature oil palms based on external symptoms. The classification of BSR disease in oil palm was identified. Confirmation of Ganoderma or BSR disease in infected oil palm were verified using the Ganoderma Selective Media (GSM). The BSR disease affected a total of 3450.70 ha (9.2\%) from this survey. As compared to other states in Malaysia, hectarage were mostly found in Johor (1032.97 ha; 487 smallholders), Sabah (930.85 ha; 252 smallholders), and Perak (718.49 ha; 410 smallholders). The disease incidence in oil palms were classified as very severe ( $>45 \%)$, severe $(31 \%-45 \%)$, moderate $(16 \%-30 \%)$, mild $(<15 \%)$ and none incidence (0\%). Areas affected with Ganoderma were found in inland (1449.29 ha; 8.72\%), followed by coastal (1266.41 ha; 14.0\%), peat (703.94 ha; 6.08\%) and lateritic (31.06 ha; 27.7\%). This study has provided information which could be useful for respective researchers, policy-makers and stakeholders on the control measures and management of the disease.
\end{abstract}

Keywords: basal stem rot, surveillance, incidence, distribution, Ganoderma, oil palm, survey, smallholders.

Date received: 26 December 2017; Sent for revision: 28 December 2017; Accepted: 1 August 2019.

\section{INTRODUCTION}

The oil palm, Elaeis guineensis Jacq., has become a major commodity crop for many countries in Africa, South-east Asia and South America (Corley and Tinker, 2003; Turner and Gillbanks, 2003). In Malaysia, the oil palm industry plays an important role in the agricultural and economic development of the country (Kushairi et al., 2018). Malaysia is

Malaysian Palm Oil Board,

6 Persiaran Institusi, Bandar Baru Bangi,

43000 Kajang, Selangor, Malaysia.

E-mail: idris@mpob.gov.my the second largest producer of palm oil with a total production of about 20 million tonnes annually (MPOB, 2018). This increase of oil palm production level is due to the grow of oil palm planted area from 5.74 million hectares in 2017 to approximately 5.81 million hectares in 2018 (MPOB, 2018). The total planted oil palm areas in Peninsular, Sabah and Sarawak were amounted to 2.70 million hectares $(46.6 \%), 1.55$ million hectares $(26.6 \%)$ and 1.56 million hectares (26.8\%), accordingly (MPOB, 2018). The smallholders occupied 2.27 million hectares, whilst the smallholders participating in replanting incentive scheme or Tanam Semula Sawit Pekebun Kecil (TSSPK) accounting to less than 0.98 million 
hectares out of the total oil palm planted area in Malaysia (Kushairi et al., 2018). All the planted areas contributed an average yield of fresh fruit bunches of $17.44 \mathrm{t} \mathrm{ha}^{-1}$ and $18.7 \mathrm{t} \mathrm{ha}^{-1}$ in 2018 and 2017, respectively. Cultivating oil palms through large scale mono-cropping is prone to serious attack of pests and diseases which could inhibit growth and hence, the yield of oil palm.

Basal stem rot (BSR) disease is the major disease caused by pathogenic Ganoderma sp. in oil palm plantations, adversely affecting smallholder especially in South-east Asia. This disease contributes to yield decrease and loss of palm stands (Idris, 2011). This has caused loss of revenues and become a serious threat to the oil palm industry in South-east Asian countries including Malaysia and Indonesia (Idris et al., 2004; Susanto et al., 2005). The estimated losses due to Ganoderma disease in oil palm amounted to RM 1.5 billion per year (Arif et al., 2011; Assis et al., 2016). The occurrence of the BSR disease has been known to attack oil palms since the early years when the crop was introduced in Malaysia (Turner, 1981). Several species had been reported as causal pathogens for BSR disease of oil palm in Malaysia, namely G. boninense, G. zonatum and G. miniatotinctum, while G. tornatum is nonpathogenic, infecting only dead trunks of oil palms (Ho and Nawawi, 1985; Idris, 1999).

The diseased palms would subsequently act as inoculum foci to cause infection to the surrounding neighbours. Infection as high as 30\%-50\% of the stand has been observed in areas severely attacked by the disease. Such a high incidence would certainly lead to an increase in the spread of the scale of inoculum load when the areas are prepared for replanting oil palm. The BSR disease symptoms typically appear in oil palms aged 25 years and above, particularly those replanted in land previously used as coconut plantation (Ariffin et al., 1996). However, the status of the BSR disease incidence have not reported in oil palm replanting areas. This article aims to report on the BSR disease incidence and distribution in oil palm plantations owned by the smallholders participants of replanting incentive scheme in Malaysia. Hence, information on the status of Ganoderma incidence in oil palms is of great importance for disease control and management.

\section{MATERIALS AND METHODS}

\section{Ground Survey}

Extension officers from MPOB conducted the ground survey in oil palms areas planted by the smallholders participating in TSSPK in Malaysia (Figure 1). This survey was conducted to detect BSR disease in oil palms areas, with a total area of 37359.81 ha involving 10292 smallholders in Peninsular, Sabah and Sarawak (Table 1). The survey consisted of visual identification of BSR disease symptoms on mature oil palms based on external symptoms as described by Idris et al. (2016). The classification of BSR disease in oil palm wasidentified (Table 2). Confirmation of Ganoderma or BSR disease in infected oil palm were verified using the Ganoderma Selective Media (GSM) (Ariffin and Idris, 1991).

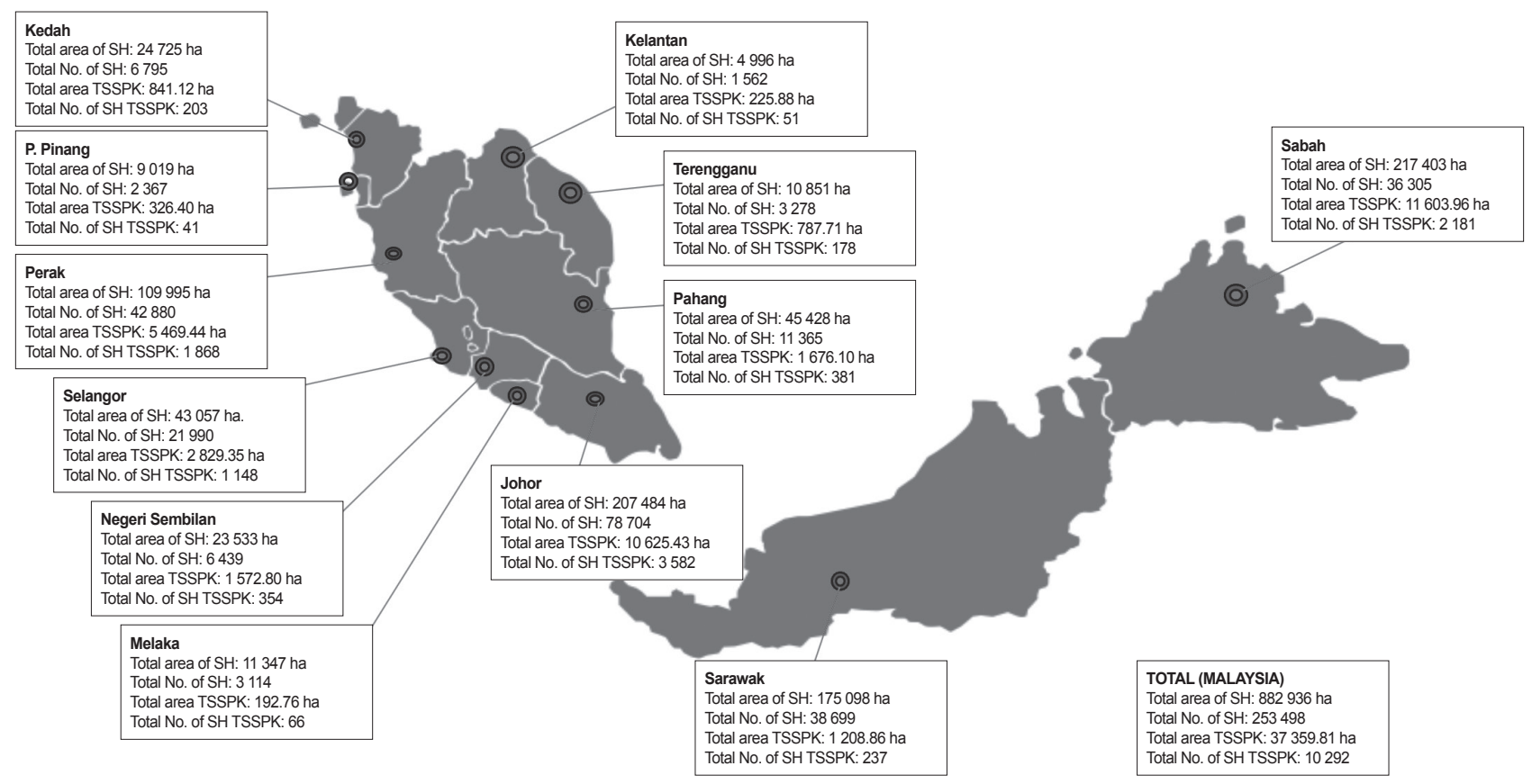

Figure 1. Description of surveyed areas and number of smallholders (SH) involved the smallholders replanting incentive scheme (TSSPK) in Malaysia. Figure not drawn to scale. 
TABLE 1. DISTRIBUTION OF THE AREA OF SMALLHOLDERS (SH) PARTICIPATING IN REPLANTING INCENTIVE SCHEME (TSSPK) INVOLVED FOR GROUND SURVEY IN MALAYSIA

\begin{tabular}{|c|c|c|c|c|}
\hline \multirow{2}{*}{ States } & \multicolumn{2}{|c|}{ SH in Malaysia } & \multicolumn{2}{|c|}{ SH surveyed } \\
\hline & Total area of SH (ha) & No. of SH & Total area of SH (ha) & No. of SH \\
\hline Johor & 207484 & 78704 & 10625.43 & 3582 \\
\hline Sabah & 217403 & 36305 & 11603.96 & 2181 \\
\hline Perak & 109995 & 42880 & 5469.44 & 1868 \\
\hline Selangor & 43057 & 21990 & 2829.35 & 1148 \\
\hline Pahang & 45428 & 11365 & 1676.10 & 381 \\
\hline Negeri Sembilan & 23533 & 6439 & 1572.80 & 354 \\
\hline Sarawak & 175098 & 38699 & 1208.86 & 237 \\
\hline Kedah & 24725 & 6795 & 841.12 & 203 \\
\hline Terengganu & 10851 & 3278 & 787.71 & 178 \\
\hline Melaka & 11347 & 3114 & 192.76 & 68 \\
\hline Kelantan & 4996 & 1562 & 225.88 & 51 \\
\hline Pulau Pinang & 9019 & 2367 & 326.40 & 41 \\
\hline Total & 882936 & 253498 & 37359.81 & 10292 \\
\hline
\end{tabular}

TABLE 2. CLASSIFICATION OF BASAL STEM ROT DISEASE IN MATURE OIL PALM

\begin{tabular}{|c|c|c|}
\hline Disease class & Disease symptom & Description \\
\hline 0 & & $\begin{array}{l}\text { Healthy/no infection. No fruiting body of G. boninense, foliar symptom or stem rotting at } \\
\text { the base. Early detection test through Ganoderma Selective Media (GSM) is negative for } \\
\text { presence of Ganoderma. }\end{array}$ \\
\hline 1 & & $\begin{array}{l}\text { Mildly infected palm or early infection. Presence of white mycelium or fruiting body of } \\
\text { G. boninense (e.g. small white button) without foliar symptoms or stem rotting }(<10 \%) \text { at the } \\
\text { base. Early detection test through GSM is positive for presence of Ganoderma. }\end{array}$ \\
\hline 2 & & $\begin{array}{l}\text { Moderately infected palm. Presence of white mycelium or fruiting body of G. boninense } \\
\text { (e.g. small white button or bracket shape). Palm showing foliar symptoms: yellowing } \\
\text { and collapsed fronds }(<50 \%) \text { and stem rotting }(<30 \%) \text { at the base. Confirmed presence of } \\
\text { Ganoderma fungus using early detection method (GSM). }\end{array}$ \\
\hline 3 & & $\begin{array}{l}\text { Severely infected palm. Presence of white mycelium or fruiting body (e.g. small white } \\
\text { button or bracket shaped). Palm showing severe foliar symptoms }(>50 \%) \text { and stem rotting } \\
(>30 \%) \text { at the base. Confirmed presence of Ganoderma fungus using early detection method } \\
(\mathrm{GSM}) \text {. }\end{array}$ \\
\hline 4 & & $\begin{array}{l}\text { Very severely infected dead palm. Presence of white mycelium or fruiting body (e.g. small } \\
\text { white button or bracket shaped). Collapsed / dead palm with severe foliar symptoms and } \\
\text { stem rotting at the base. Confirmed presence of Ganoderma fungus using early detection } \\
\text { method (GSM). }\end{array}$ \\
\hline
\end{tabular}

Note: Palm age is more than 25 years old. Source: Idris et al. (2016). 


\section{Disease Incidence}

The classification of BSR disease incidence in oil palm areas of smallholders were classified (Table 3) as modification of BSR disease severity indices (DSI) were developed earlier (Idris et al., 2016; Izzuddin et al., 2017) for classification based on the visual symptoms. The BSR disease incidence was calculated as follows:

$$
\text { Total affected area with }
$$

$\begin{gathered}\text { BSR disease } \\ \text { incidence }(\%)\end{gathered}=\frac{\text { BSR disease (ha) }}{\begin{array}{c}\text { Total oil palm planting } \\ \text { area (ha) }\end{array}} \times 100$

TABLE 3. CLASSIFICATION OF BSR DISEASE INCIDENCE

\begin{tabular}{ccc}
\hline Class & Description & BSR disease incidence (\%) \\
\hline 0 & None & 0 \\
1 & Mild & $0.1-15$ \\
2 & Moderate & $16-30$ \\
3 & Severe & $31-45$ \\
4 & Very Severe & $>45$ \\
\hline
\end{tabular}

Note: Palm age is more than $>25$ years old.

Modification of basal stem rot (BSR) disease severity indices (DSI) were developed by Idris et al. (2016) for classification of oil palm based on the visual symptoms.

\section{Soil Types}

Determination of soil types were carried out based on local area of smallholders referred to the Peninsular Malaysia Reconnaissance Soil, Soil Management Division, Department of Agriculture, Peninsular Malaysia (1962), Sabah Reconnaissance Soil, Department of Agriculture (DOA) (1974) and Sarawak Reconnaissance Soil, DOA (1968) from the Agronomy and Geospatial Technology Unit, MPOB (MPOB, 2017a).

\section{RESULTS AND DISCUSSION}

\section{Areas Affected with Ganoderma Disease in Smallholders of TSSPK}

Based on the 10292 smallholders surveyed, a total of 1528 smallholders were affected with BSR disease in their planted oil palm areas comprising a total of 3450.70 ha out of 37359.81 ha of matured oil palms (Figure 2 and Table 4). The highest BSR disease incidence was recorded in Johor at 1032.97 ha affecting 487 smallholders followed by Sabah (930.85 ha; 252 smallholders) and Perak (718.49 ha; 410 smallholders). In the survey, Kluang, Johor recorded the highest incidence of BSR at 333.48 ha $(62.94 \%)$ affecting 175 smallholders followed by Segamat (290.77 ha or 50.55\%) whereby 125 smallholders were affected, Hilir Perak (350.97 ha or $55.43 \%)$, Manjung (267.84 ha or $64.32 \%)$, Miri (120.0 ha or $15.58 \%)$ and Lahad Datu (307.70 ha or $54.5 \%$ ) (MPOB, 2017b). BSR disease incidence was reported confined to the coastal areas, where the incidence may reach $85 \%$, particularly in replanted areas reaching 25 years after planting, with no control methods being adopted (Ariffin et al., 2000). Nevertheless, to date, BSR disease incidences have been found as major devastating disease in planted oil palm particularly in Malaysian smallholders areas (Idris et al., 2014; Mohd Shukri et al., 2015). In seriously cases, presence of symptomatic of the BSR disease were reported to attack on oil palms at four years after planting in field plantations (Ariffin and Basri, 2000).

\section{BSR Disease Incidence in Oil Palms Planted by TSSPK's Smallholders}

Based on the survey obtained, 893 smallholders from districts of Kluang and 300 smallholders from Segamat, Johor; Port Dickson and Jempol, Negeri Sembilan (67 smallholders); Hilir Perak and Manjung, Perak (278 smallholders); Kuala Langat and Sabak Bernam, Selangor (151 smallholders); and in Lahad Datu, Sabah (97 smallholders) were categorised as very severe class of BSR incidence $(>45 \%)$ (Figure 2). Whilst, 83 smallholders of TSSPK schemes from districts in Sandakan, Miri, and several districts in Peninsular were observed with severe class of BSR disease incidence $(31 \%-45 \%)$ as in Figure 2. About 239 smallholders in Pulau Pinang, Kedah and southern region of Pahang and Johor reported the presence of BSR disease in moderate class (16\%-30\%) (Figure 2). A total of 313 smallholders were in the mild class $(<15 \%)$ (Figure 2$)$ and they were scattered throughout Peninsular, Sabah and Sarawak. No BSR disease was reported by the smallholders of TSSPK's schemes in Kedah and Kelantan due to a smaller number of smallholders participating in TSSPK.

According to Turner (1965) and Pilotti (2005), high incidences were observed in palms replanted on areas formerly infected with Ganoderma, where the infected stumps were retained on the ground. Visual symptoms can be observed as early as 12-24 months after planting and the infection will be visible after five years (Rees et al., 2012). Infected young palms normally die within 6-12 months, but it takes 1-2 years for mature palms to die (Naher et al., 2015). Ganoderma disease incidence in oil palms could reach up to $51 \%$ after 15 years of replanting on land previously used for coconut tree cultivation (Singh, 1991). Meanwhile, replanting oil palms in existing oil palm areas without proper replanting techniques had been identified as one of the 
reasons for high Ganoderma incidence (Turner and Gillbanks, 2003). In this case, Ganoderma disease can be detected as early as five years after planting and could reach up to $42 \%$ after 15 years (Idris, 2012). Low incidences were reported in oil palms planted in former rubber plantation areas or in the main forest due to scarcity of inoculum of Ganoderma in these areas in comparison with other precedent crops (e.g. oil palms and coconut trees) (Rees et al., 2009).

TABLE 4. BASAL STEM ROT (BSR) DISEASE INCIDENCE (\%) AND NUMBER OF AFFECTED SMALLHOLDERS (SH) PARTICIPATING IN REPLANTING INCENTIVE SCHEME (TSSPK)

\begin{tabular}{lcccc}
\hline States & $\begin{array}{c}\text { Area of SH with } \\
\text { BSR disease (ha) }\end{array}$ & $\begin{array}{c}\text { BSR disease } \\
\text { incidence (\%) }\end{array}$ & $\begin{array}{c}\text { No. of SH with } \\
\text { BSR disease }\end{array}$ & $\begin{array}{c}\text { Affected SH } \\
\text { (\%) }\end{array}$ \\
\hline Johor & 1032.97 & 9.72 & 487 & 13.60 \\
Sabah & 930.85 & 8.02 & 252 & 11.55 \\
Perak & 718.49 & 13.14 & 410 & 21.95 \\
Selangor & 407.08 & 14.39 & 202 & 17.60 \\
Pahang & 35.0 & 2.10 & 24 & 6.30 \\
Negeri Sembilan & 114.60 & 7.29 & 70 & 19.77 \\
Sarawak & 135.0 & 11.17 & 55 & 23.21 \\
Kedah & 0 & 0 & 0 & 0 \\
Terengganu & 22.0 & 2.79 & 14 & 7.87 \\
Melaka & 14.7 & 7.63 & 3 & 4.55 \\
Kelantan & 0 & 0 & 0 & 0 \\
Pulau Pinang & 40.0 & 12.25 & 11 & 26.83 \\
\hline Total & 340.70 & 9.24 & 1528 & 14.85 \\
\hline
\end{tabular}

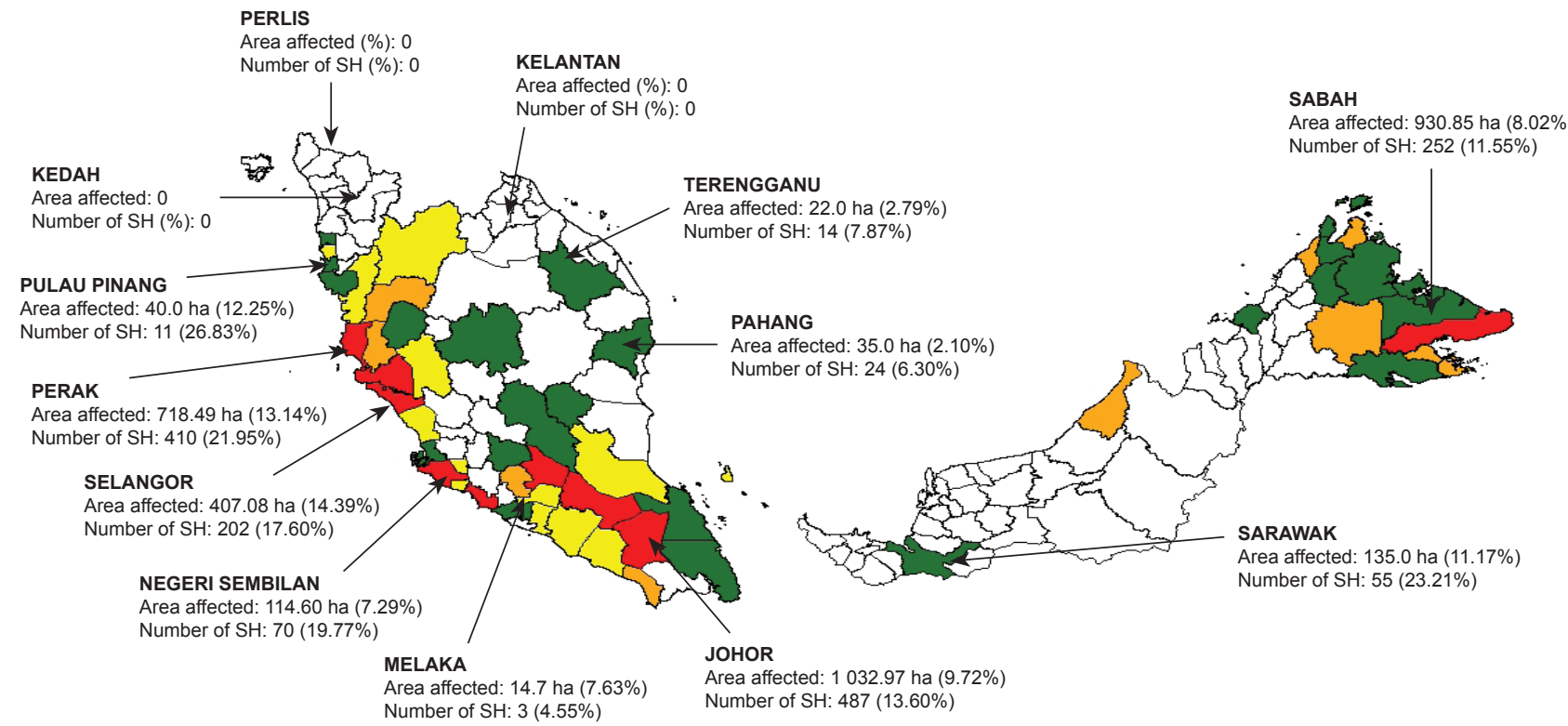

TOTAL (MALAYSIA)

Area affected: 3450.70 ha $(9.24 \%)$

Number of SH: $1528(14.85 \%)$

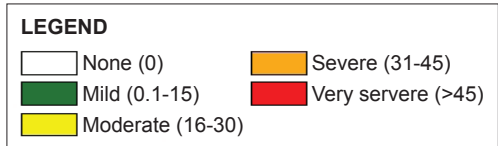

Figure 2. Distribution of basal stem rot (BSR) disease incidence of oil palm in smallholders (SH) participating in the replanting incentive scheme (TSSPK) in Malaysia according to oil palm planted areas (ha) and number of SH affected with BSR disease. Figure not drawn to scale. 


\section{Ganoderma Disease Incidence According to Soil Type}

Incidence of the BSR disease was commonly described as soil-borne disease. However, there is no scientific proven that it was spread due to any particular soil types. Ganoderma infection spreads through roots especially without BSR disease control. In Malaysia, the BSR disease has not been reported to be parasitic to coconut but could grow only as saprophyte in dead coconut tissues (Ariffin et al., 2000). It is in this form that fungus survives and remains infective (Ariffin et al., 1996). Left buried in soil, these infected tissues serve as the sources of inoculum and could initiate infection on contact with oil palm roots (Flood et al., 2000; Cooper et al., 2011; Ariffin et al., 2000).

BSR disease incidences were reported presence in oil palm planted by smallholders involving TSSPK schemes particular in several districts in Selangor (Parthiban et al., 2017). In this survey, we recorded the BSR disease incidence in all states in Malaysia including Peninsular, Sabah and Sarawak. Based on cumulative area of the BSR incidence of oil palm according to soil types BSR disease were mainly recorded in inland soil covering 1449.29 ha (out of $16 \quad 625.16$ ha) followed by coastal soil with coverage of 1266.41 ha (out of 9041.04 ha), peat soil at 703.94 ha (out of $11581.54 \mathrm{ha}$ ) and lateritic soil at 31.06 ha (out of $112.07 \mathrm{ha}$ ) (Table 5). In addition, the highest BSR disease incidence was recorded in lateritic $(27.70 \%)$ followed by coastal, inland and peat at $14.00 \%, 8.72 \%$ and $6.08 \%$, respectively. Several BSR disease incidences on mature oil palms were previously reported, mainly in Johor of $50 \%$ and Negeri Sembilan of $11.70 \%$ (Benjamin and Chee, 1995). In this survey, all the soil types in oil palm plantation were susceptible to the BSR disease. All soil types were previously thought as nonconducive to Ganoderma disease, but this is no longer true.

Infected oil palm roots and stumps left buried in soil have been reported as the primary source for Ganoderma inoculum in oil palm plantations (Flood et al., 2000). The root contact with unattended infected debris left in the plantations during replanting is known to be the primary source of infection spread (Idris et al., 2003). Devastation caused by Ganoderma had apparently showed rapid increase as a result from subsequent massive debris of oil palm infected tissues which contributed to a large amount of accumulated field inoculum from the previous crop (Khairudin and Tey, 2008). The risk of outbreak of this disease is intensified along with active oil palms replanting in smallholders' lands and estates that have history of the disease.
TABLE 5. BASAL STEM ROT (BSR) DISEASE INCIDENCE (\%) AND AFFECTED AREAS (ha) ACCORDING TO SOIL TYPES

\begin{tabular}{lccc}
\hline Soil types $^{\mathbf{1}}$ & $\begin{array}{c}\text { Surveyed area } \\
\text { (ha) }\end{array}$ & $\begin{array}{c}\text { BSR affected } \\
\text { area (ha) }\end{array}$ & $\begin{array}{c}\text { BSR disease } \\
\text { incidence }^{\mathbf{3}} \mathbf{( \% )}\end{array}$ \\
\hline Peat & 11581.54 & 703.94 & 6.08 \\
Inland & 16625.16 & 1449.29 & 8.72 \\
Coastal & 9041.04 & 1266.41 & 14.00 \\
Lateritic & 112.07 & 31.06 & 27.71 \\
\hline
\end{tabular}

Note: ${ }^{1}$ Common soil type used in oil palm plantations.

${ }^{2}$ Particularly involved oil palm age $>25$ years old.

${ }^{3}$ BSR disease incidence (\%) on the affected smallholders participating in replanting incentive scheme (TSSPK).

\section{CONCLUSION}

BSR disease incidences in Malaysia are increasing alarmingly particularly in smallholder areas where control measures are not prevalent. This study shows the occurrence of BSR disease in all type of soils mainly inland and coastal soils with total infected area managed by surveyed smallholders at 3450.70 ha. The most affected areas were in Johor (1032.97 ha), Sabah (930.85 ha), and Perak (718.49 ha). The disease incidences will keep on increasing if mitigation and control measures are not implemented particularly in the smallholders areas. The disease incidence in oil palm smallholders areas was classified as very severe $(>45 \%)$, severe $(31 \%$ $45 \%)$, moderate $(16 \%-30 \%)$, mild $(<15 \%)$ and no incidence $(0 \%)$. Areas affected by Ganoderma were found in inland (1449.29 ha; 8.72\%), followed by coastal (1266.41 ha; $14.00 \%)$, peat (703.94 ha; $6.08 \%$ ) and lateritic (31.06 ha; 27.70\%). It was suggested to investigate in others oil palm areas such as in plantations or estates for comparison study. MPOB has developed several control measures and methods to control Ganoderma infestation in oil palm. Procedures such as sanitation technique through removing or destroying the BSR infected palms, fungicide control using hexaconazole, biological control agents and fertiliser formulations with beneficial microbes were being introduced to the smallholders. Hence, knowledge on the status of Ganoderma incidence in oil palms is of great importance for oil palm stakeholders for disease control and management.

\section{ACKNOWLEDGEMENT}

We would like to thank the Director-General of MPOB for permission to publish this study. Thanks also to Deputy Director-General (R\&D) of MPOB for support and comments on this study as well as to all extension officers, namely, Parthiban Kannan, Amran Ariffin, Shakir Alid, Arfan Johari, Khairul 
Abidin, Shafirul Ab Wahab, Khairul Anuar Isnin, Nursuhana Dahari and Hasmiza Desa who have provided support and cooperation throughout the research process. We also would like to acknowledge the assistance and cooperation from the staff of MPOB and smallholders participated in this survey.

\section{REFERENCES}

Ariffin, D and Idris, A S (1991). A selective medium for the isolation of Ganoderma from diseased tissues. Proc. of the 1991 International Palm Oil Conference Progress, Prospects and Challenges - Towards the 21 $1^{\text {st }}$ Century (Model 1, Agriculture) (Ariffin, D; Yusof, B and Basri, M W eds.). PORIM, Bangi. p. 517-519.

Ariffin, D; Idris, A S and Marzuki, A (1996). Spread of Ganoderma boninense and vegetative compatibility studies of a single field palm isolates. Proc. of the 1996 PORIM International Palm Oil Congress: Competitiveness for the $21^{\text {st }}$ Century (Agriculture Conference) (Arifin, D; Basri, M W; Rajanaidu, N; Mohd Tayeb, D; Paranjothy, K; Cheah, S C; Chang, K C and Ravigadevi, S eds.). PORIM, Bangi. p. 508-515.

Ariffin, D; Idris, A S and Singh, G (2000). Status of Ganoderma in oil palm. Ganoderma Diseases of Perennial Crops (Flood, J; Bridge, P D and Holderness, M eds.). CABI Publishing, Oxford, United Kingdom. 49 pp.

Ariffin, D and Basri, M W (2000). Intensive IPM for management of oil palm pests. Oil Palm Bulletin No. 41: 1-14.

Arif, M A; Roslan, A; Idris, A S and Ramle, M (2011). Economics of oil palm pests and Ganoderma diseases and yield loss. Proc. of the $3^{\text {rd }}$ International Seminar Integrated Oil Palm Pests and Diseases Management. MPOB, Bangi. p. 83-98.

Assis, K; Idris, A S and Ho, C M (2016). Economic loss due to Ganoderma disease in oil palm. Economic and Management Engineering, 10(2): 631-635.

Benjamin, M and Chee, K H (1995). Basal stem rot of oil palm a serious problem on inland soils. Malaysian Plant Protection Society MAPPS Newsletter, 19(1): 3.

Cooper, R M; Flood, J and Rees, R W (2011). Ganoderma boninense in oil palm plantations: Current thinking on epidemiology, resistance and pathology. The Planter, 87(2): 515-526.

Corley, R H V and Tinker, P B (2003). Chapter 1: The origin and development of the oil palm industry. The Oil Palm. Fourth edition. Blackwell Publishing, United States. p. 1-26.
Flood, J; Hasan, Y; Turner, P D and O'Grady, E B (2000). The spread of Ganoderma from infective sources in the field and its implications for management of the disease in oil palm. Ganoderma Diseases in Perennial Crops (Flood, J; Bridge, P D and Holderness, M eds.). CABI Publishing, Oxford, United Kingdom. p. 101112.

Ho, Y W and Nawawi, A (1985). Ganoderma boninense Pat. from basal stem rot of oil palm (Elaeis guineensis) in Peninsular Malaysia. Pertanika J. Trop. Agric. Sci., 8(3): 425-428.

Idris, AS (1999). Basal Stem Rot (BSR) of Oil Palm (Elaeis guineensis Jacq.) in Malaysia: Factors Associated with Variation in Disease Severity. Ph.D thesis, Wye College University of London, United Kingdom. 322 pp.

Idris, A S (2011). Biology, detection, control and management of Ganoderma disease in oil palm. Further Advances in Oil Palm Research (2000-2010) (Basri, M W; Choo, Y M and Chan, K W eds.). MPOB, Bangi. p. 485521.

Idris, A S (2012). Latest research and management of Ganoderma disease in oil palm. Proc. of the Fourth IOPRI-MPOB International Seminar: Existing and Emerging Pests and Diseases of Oil Palm Advances in Research and Management. IOPRI, Indonesia. p. 1-23.

Idris, A S; Ariffin, D and Ismail, S (2003). Interaction between Ganoderma and leguminous cover crop - Pathogenicity and field observation in oil palm plantation. Proc. of the PIPOC 2003 International Palm Oil Congress - Agriculture Conference. MPOB, Bangi. p. 1020-1025.

Idris, A S; Kushairi A; Ismail, S and Ariffin, D (2004). Selection for partial resistance in oil palm progenies to Ganoderma basal stem rot. J. Oil Palm Res. Vol. 16: 12-18.

Idris, A S; Mior, M H A Z; Maizatul, S M and Kushairi, A (2011). Survey on status of Ganoderma disease in oil palm in Malaysia 2009-2010. Proc. of the PIPOC 2011 International Palm Oil Congress - Agriculture, Biotechnology \& Sustainability Conference. MPOB, Bangi. p. 235-238.

Idris, A S; Mohd Shukri, I; Norman, K and Kushairi, A (2014). Survey on status of basal stem rot disease in oil palm smallholders in Malaysia 2011-2013. Prosiding Persidangan Pekebun Kecil Sawit Kebangsaan 2014. $\mathrm{MPOB}$, Bangi. p. 1-14.

Idris, A S; Nurrashyeda, R; Rusli, M H; Shamala, S and Norman, K (2016). Standard Operating Procedures (SOP) Guidelines for Managing Ganoderma Disease in Oil Palm. MPOB, Bangi. p. 1-36. 
Izzuddin, M A; Idris, A S; Nisfariza, M N; Nordiana, A Z; Mohd Shafri, H Z and Ezzati, B (2017). The development of spectral indices for early detection of Ganoderma disease in oil palm seedlings. Intern. J. Remote Sensing, 38(27): 6505-6527.

Khairudin, H and Tey, C C (2008). An overview of the current status of Ganoderma basal stem rot and its management in a large plantation group in Malaysia. The Planter, 84(988): 469-480.

Kushairi, A; Singh, R and Ong-Abdullah, M (2017). The oil palm industry in Malaysia: Thriving with transformative technologies. J. Oil Palm Res. Vol. 29(4): 431-439.

Kushairi, A; Loh, S K; Azman, I; Hishamuddin, E; Meilina Ong-Abdullah; Zanal Bidin Mohd Noor Izuddin; Razmah, G; Shamala Sundram and Parveez, G K A (2018). Oil palm economic performance in Malaysia and R\&D progress in 2017. J. Oil Palm Res. Vol. 30(2): 163-195.

Mohd Shukri, I; Idris, A S; Izzuddin, M A; Norman, K; Mad Hashim, O; Izuddin, Z B N; Khairuman, $\mathrm{H}$ and Hamdan, A B (2015). Ground survey of Ganoderma disease in oil palm planted by smallholders in Malaysia. Proc. of the PIPOC 2015 International Palm Oil Congress and Exhibition - Agriculture, Biotechnology and Sustainability Conference. Vol. II. MPOB, Bangi. p. 235-238.

MPOB (2017a). Agronomy and Geospatial Technology Unit. Unpublished data, MPOB, Bangi.

MPOB (2017b). Ganoderma and Diseases Research for Oil Palm Unit. Unpublished data, MPOB, Bangi.

MPOB (2018). Malaysian Oil Palm Statistics 2017. 37 ed. MPOB, Bangi. Selangor. 205 pp.

Naher, L; Shafiquzzaman, S; Umi Kalsom, Y and Mondal, M M A (2015). Issues of Ganoderma sp. and basal stem rot disease management in oil palm. Am. J. of Agric. Sci., 2(3): 103-107.

Parthiban, K; Tan, S P; Siti Mashani, A; Idris, A S; Ayatollah Khomeini, A R; Khairuman, H; Hamdan, A $\mathrm{B}$ and Wahid, O (2017). Knowledge assessment of basal stem rot disease of oil palm and its control practices among recipients of replanting assistance scheme in Malaysia. Inter. J. Agric. Res., 12: 73-81.

Pilotti, C A (2005). Stem rots of oil palm caused by Ganoderma boninense: Pathogen biology and epidemiology. Mycopathologia, 159: 129-137.

Rees, R W; Flood, J; Hasan, Y; Potter, U and Cooper, R $\mathrm{M}$ (2009). Basal stem rot of oil palm (Elaeis guineensis); Mode of root infection and lower stem invasion by Ganoderma boninense. Plant Pathology, 58(5): 982-989.

Rees, R W; Flood, J; Hasan, Y; Wills, M A and Cooper, R M (2012). Ganoderma boninense basidiospores in oil palm plantations: Evaluation of their possible role in stem rots of Elaeis guineensis. Plant Pathology, 61(3): 567578.

Singh, G (1991). Ganoderma - The scourge of oil palms in the coastal areas. The Planter, 67(786): 421-444.

Susanto, A; Sudharto, P S and Purba, R Y (2005). Enhancing biological control of basal stem rot disease (Ganoderma boninense) in oil palm plantations. Mycopathologia, 159: 153-157.

Turner, P D (1965). The incidence of Ganoderma disease of oil palms in Malaya and its relation to previous crop. Annals of Applied Biology, 55(3): 417-423.

Turner, P D (1981). Oil Palm Diseases and Disorders. Oxford University Press, Oxford. p. 88-110.

Turner, P D and Gillbanks, R A (2003). Oil Palm Cultivation and Management. The Incorporated Society of Planters (ISP). Kuala Lumpur, Malaysia. 672 pp. 